\title{
Potassium multiphosphates for food processing
}

\author{
Barbara Cichy' ${ }^{1}$, Stanisław Folek ${ }^{1}$, Halina Makała ${ }^{2}$ \\ ${ }^{1}$ Institute of Inorganic Chemistry in Gliwice, e-mail: bcichy@ichn.gliwice.pl \\ ${ }^{2}$ Meat and Fat Research Institute in Warsaw
}

\begin{abstract}
The paper discusses the results of research on the preparation of food grade potassium di- and triphosphates and the application thereof as multiphosphate ingredients of functional additives for meat processing. The research on the process of potassium multiphosphate manufacture was performed with the use of equipment corresponding to that used on an industrial scale, facilitating thereby the transfer of the process conditions to a commercial level. The aim of the work was to obtain potassium di- and triphosphate products readily soluble in water and $\mathrm{NaCl}$ solutions, determination of optimum parameters of the manufacturing processes, and an application of the products obtained along with sodium multiphosphates in functional phosphate additives for selected meat products. The research presented here is part of an on-going project.
\end{abstract}

Keywords: food additive, multiphosphate.

Presented at VII Conference Wasteless Technologies and Waste Management in Chemical Industry and Agriculture, Międzyzdroje, 12 - 15 June, 2007.

\section{INTRODUCTION}

Phosphates, including multiphosphates (polyphosphates), are widely used in the food industry. They form part of a group of the products defined in the Ordinance of the Minister of Health of 23 April 2004 (Dz. U. 04.94.933) as „,food additives” classified as: „,acidity regulators and stabilisers"1. They are applied in various branches of food processing. Of particular importance is their use in meat processing. Multiphosphates, added to the food in various forms, hydrolyse to monophosphates which are assimilated by the human organism in metabolic processes together with natural phosphates present in the food. The effects of phosphate application include: reduction of thermal drip, product shape stabilization, improved juiciness and tenderness, better binding of meat chunks, better colour development and stability and improved microbial quality ${ }^{2}-5$.

Since 2 July 2003 the Polish regulations, harmonized with the EU law, allow the use of phosphates in meat products in quantities not exceeding $5000 \mathrm{mg} \mathrm{P}_{2} \mathrm{O}_{5} / \mathrm{kg}$ product. They can be used not only for pickled whole muscle products (smoked meat, ham, preserved shoulder) as was the case before the date mentioned above, but also in the production of all other meat and poultry products. The maximum daily tolerated intake (MDTI) is $70 \mathrm{mg} / \mathrm{kg}$ of body weight, including phosphates of muscle origin ${ }^{6}$.

Phosphates also play a particular role in low-salt dietetic products. By introducing $0.35-0.5 \%$ of polyphosphates, the salt concentration in food products can be reduced from $2.5 \%$ to $1.5 \%$. Further reduction of sodium content in the low-sodium dietetic products can be achieved by replacing a portion of sodium phosphate with potassium phosphate ${ }^{7}$. Human organism needs only $1 \mathrm{~g}$ of salt per day for its physiological processes. However, people in Poland eat as much as $15-20 \mathrm{~g}$ of salt each day. Excessive amount of salt consumed, particularly by those susceptible to hypertension, can be hazardous. The kidneys of the people sensitive to salt are more prone to retain the salt. The high-sodium diet consumed by people with hypertension may lead to accelerated atherogenesis, ischaemic heart disease and elevated risk of apo- plectic stroke. Therefore, a reduced quantity of salt in the diet can help lower blood pressure. The World Health Organization (WHO) recommends that the daily salt intakes should not exceed $6 \mathrm{~g}$ per person. The effects of various phosphate preparations are varied and depend, among other things, on the type of phosphorus compounds included, the type of the cation linked to phosphorus, the length of phosphate (multiphosphate) molecule chain and $\mathrm{pH}$ value ${ }^{8-10}$. However, there are no detailed research reports on the effect of the various phosphate types used in blends, in qualitative and quantitative terms, on processing and sensory properties of food products.

Sodium and potassium di- and triphosphates are obtained by neutralizing phosphoric acid with hydroxides or carbonates up to appropriate $\mathrm{Na}_{2} \mathrm{O}$ or $\mathrm{K}_{2} \mathrm{O} / \mathrm{P}_{2} \mathrm{O}_{5}$ molar ratio. The solutions of orthophosphates, during intensive heating, are concentrated, evaporated and condensed to multiphosphates. The descriptions of sodium phosphate preparation found in the literature are much more numerous than those of analogous potassium salts. Despite close similarity, there are specific problems characteristic of potassium multiphosphate synthesis ${ }^{11,12}$.

The preparation of tetrapotassium diphosphate can be described by the following equations:

$\mathrm{H}_{3} \mathrm{PO}_{4}+2 \mathrm{KOH} \rightarrow \mathrm{K}_{2} \mathrm{HPO}_{4}+2 \mathrm{H}_{2} \mathrm{O}$

Tetrapotassium diphosphate $\mathrm{K}_{4} \mathrm{P}_{2} \mathrm{O}_{7}$ is obtained by thermal decomposition of $\mathrm{K}_{2} \mathrm{HPO}_{4}$ at a temperature above $350^{\circ} \mathrm{C}$.

$2 \mathrm{~K}_{2} \mathrm{HPO}_{4} \rightarrow \mathrm{K}_{4} \mathrm{P}_{2} \mathrm{O}_{7}+\mathrm{H}_{2} \mathrm{O}$

This compound has two crystalline forms: low- and high-temperature, both of which are water soluble and highly hygroscopic. It can crystallize in the form of a trihydrate, which decomposes at $105^{\circ} \mathrm{C}$ with evolution of water.

Chemical reactions that occur during triphosphate preparation follow the following equations:

$\mathrm{H}_{3} \mathrm{PO}_{4}+\mathrm{KOH} \rightarrow \mathrm{KH}_{2} \mathrm{PO}_{4}+\mathrm{H}_{2} \mathrm{O}$

$\mathrm{KH}_{2} \mathrm{PO}_{4}+\mathrm{KOH} \rightarrow \mathrm{K}_{2} \mathrm{HPO}_{4}+\mathrm{H}_{2} \mathrm{O}$

Condensation of a mixture of $\mathrm{KH}_{2} \mathrm{PO}_{4}$ and $\mathrm{K}_{2} \mathrm{HPO}_{4}$ at a molar ratio of $1: 2$ and temperature above $250^{\circ} \mathrm{C}$ leads 
to pentapotassium tripolyphosphate: $\mathrm{K}_{5} \mathrm{P}_{3} \mathrm{O}_{10}$. The condensation reaction follows the equation:

$\mathrm{KH}_{2} \mathrm{PO}_{4}+2 \mathrm{~K}_{2} \mathrm{HPO}_{4} \rightarrow \mathrm{K}_{5} \mathrm{P}_{3} \mathrm{O}_{10}+2 \mathrm{H}_{2} \mathrm{O}$

During the dehydration of a mixture of potassium monoand dihydrogen phosphate (2:1 molar ratio), depending on the temperature, various phases of triphosphate, metaphosphates and minor amounts of pyrophosphate may coexist. Appropriate yield under technical conditions is obtained at the temperatures of 400 to $450^{\circ} \mathrm{C}$. The yield of the process depends on the temperature. Metaphosphates, which are formed in a competitive side reaction, have a disadvantageous effect on the solubility and nutritional availability of phosphates ${ }^{\mathbf{1 3}}$.

$\mathrm{nKH}_{2} \mathrm{PO}_{4} \stackrel{\Delta}{\longrightarrow}\left(\mathrm{KPO}_{3}\right)_{\mathrm{n}}+\mathrm{n} \mathrm{H}_{2} \mathrm{O}$

The process conditions determine the quality and purity of the products. Certain amounts of unreacted orthophosphates occur in multiphosphates seem to have an advantageous effect on the properties of the food grade products. Metaphosphates, which are formed in competitive side reactions, have a disadvantageous effect on the solubility and nutritional availability of phosphates. Potassium salts are highly hygroscopic and tend to adopt amorphous forms. Retention of the proper moisture level in products and intermediates and a proper grain size distribution of the product may determine its applicability in food grade additive blends, which should retain flowability in the solid state and high solubility in water.

The aim of the work was to obtain potassium di- and triphosphate products readily soluble in water and in $\mathrm{NaCl}$ solutions, determination of optimum parameters of the manufacturing processes, and application of the products obtained along with sodium multiphosphates in functional phosphate additives for selected meat products. Research on the process of potassium multiphosphate manufacture was performed with the use of equipment corresponding to that used on an industrial scale, facilitating thereby the transfer of process conditions to a commercial level.

\section{MATERIALS AND RESEARCH METHODS}

Research methodology included two stages:

1) obtaining and preparing phosphate blends for application studies,

2) practical application of the prepared phosphate blends in model meat products.

Potassium multiphosphates - tetrapotassium diphosphate and pentapotassium triphosphate - and mixtures thereof were obtained on a large laboratory scale in processes listed below.

1. Neutralization of food grade phosphoric acid (77\% $\mathrm{P}_{2} \mathrm{O}_{5}$ ) with pure $\mathrm{KOH}$ solution $(45 \% \mathrm{KOH})$. The reaction was carried out in a closed glass reactor equipped with a stirrer and thermometer and connected to a metering pump. The temperature of the process $\left(60-80^{\circ} \mathrm{C}\right)$ was attained due to the reaction heat and is maintained by adjusting the potash lye feed rate. A series of tests were conducted, these tests consisting in the neutralization end points corresponding to the $\mathrm{K}_{2} \mathrm{O} / \mathrm{P}_{2} \mathrm{O}_{5}$ molar ratios (TM) of between 1.2 to 2.0. The tests provided solutions or suspensions containing mixtures of $\mathrm{KH}_{2} \mathrm{PO}_{4}$ and $\mathrm{K}_{2} \mathrm{HPO}_{4}$. The neutralization end point was determined by acid-base titration using phenolphthalein and methyl orange as indicators.
2. Spray drying of the solution obtained (if the neutralization reaction yielded a suspension, the latter was diluted to less than saturation concentration for the given system) by means of a Niro A/S Mobile Minor TM 2000 model $\mathrm{H}$ dryer with water evaporative capacity of $1-7 \mathrm{~kg} / \mathrm{h}$. Maximum operating temperatures: inlet air $350^{\circ} \mathrm{C}$, outlet air $120^{\circ} \mathrm{C}$. A rotary atomizer with an air turbine drive was used to spray the suspension.

3. Calcination was conducted on metal trays, each with a capacity of $0.5 \mathrm{~kg}$, in a Nabertherm N60/65HA chamber furnace providing automatic temperature control in the range of $20-650^{\circ} \mathrm{C}$ in steps of $1^{\circ} \mathrm{C}$. Tests were performed in the temperature range of $300-500^{\circ} \mathrm{C}$ and within reaction times $40-60$ minutes. Under these conditions the conversion rate $(\mathrm{K})$ of orthophosphates to multiphosphates exceeded $98 \%$ (for TM $1.5-2.0$ ). The conversion rate $\mathrm{K}$ was calculated as the ratio of non-ortho phosphates to the total phosphates, whereas the total phosphates were determined, after sample hydrolysis in hot hydrochloric acid, by titration with magnesium chloride standard solution in alkaline water-alcohol medium using thymolphthalexon and phenolphthalein as indicators. Orthophosphate content was determined using molybdenum colorimetric method in acidic medium at $650 \mathrm{~nm}$ wavelength.

Upon calcination and comminution a series of products was obtained. These products comprised mixtures of tetrapotassium diphosphate and pentapotassium triphosphate with a minor content of tripotassium orthophosphate. In addition to total phosphate and orthophosphate content, the percentage of di- and triphosphates was determined using high performance liquid chromatography (HPLC). The content of residue insoluble in the water was also determined using the method according to Polish Standard PN-93/C84300/21. The separated water insoluble phase was analyzed on a Philips 1140 X-ray diffractometer. The following products were selected for application tests in blends with sodium di- and

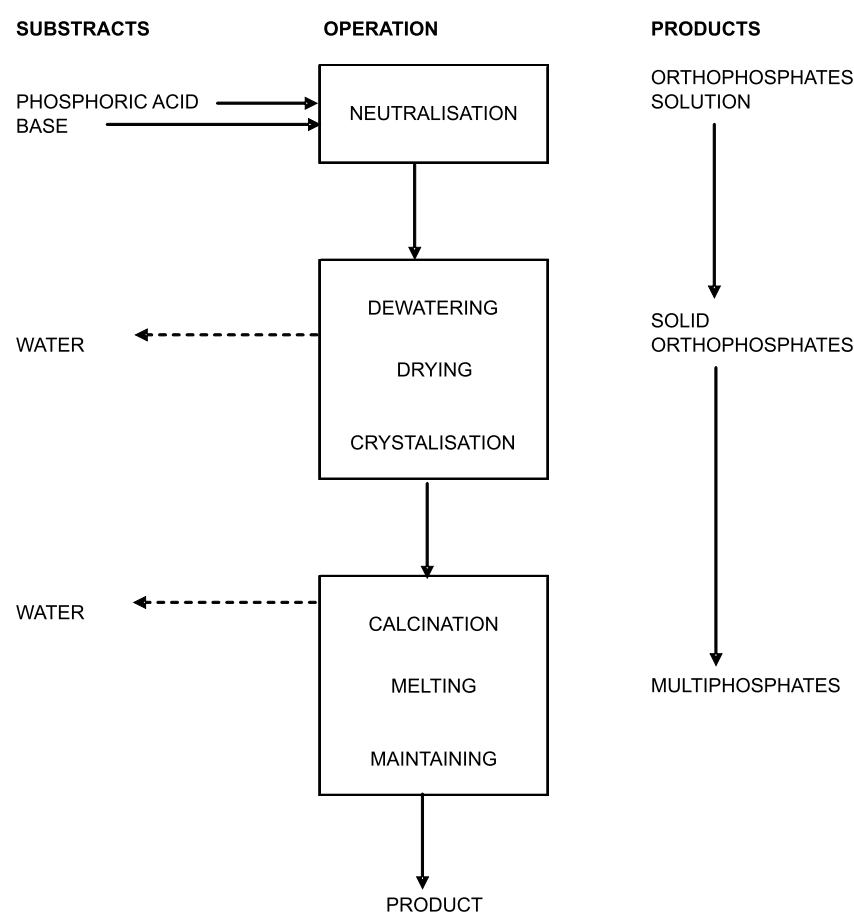

Figure 1. A Diagram of the Multiphosphate Production Proces 


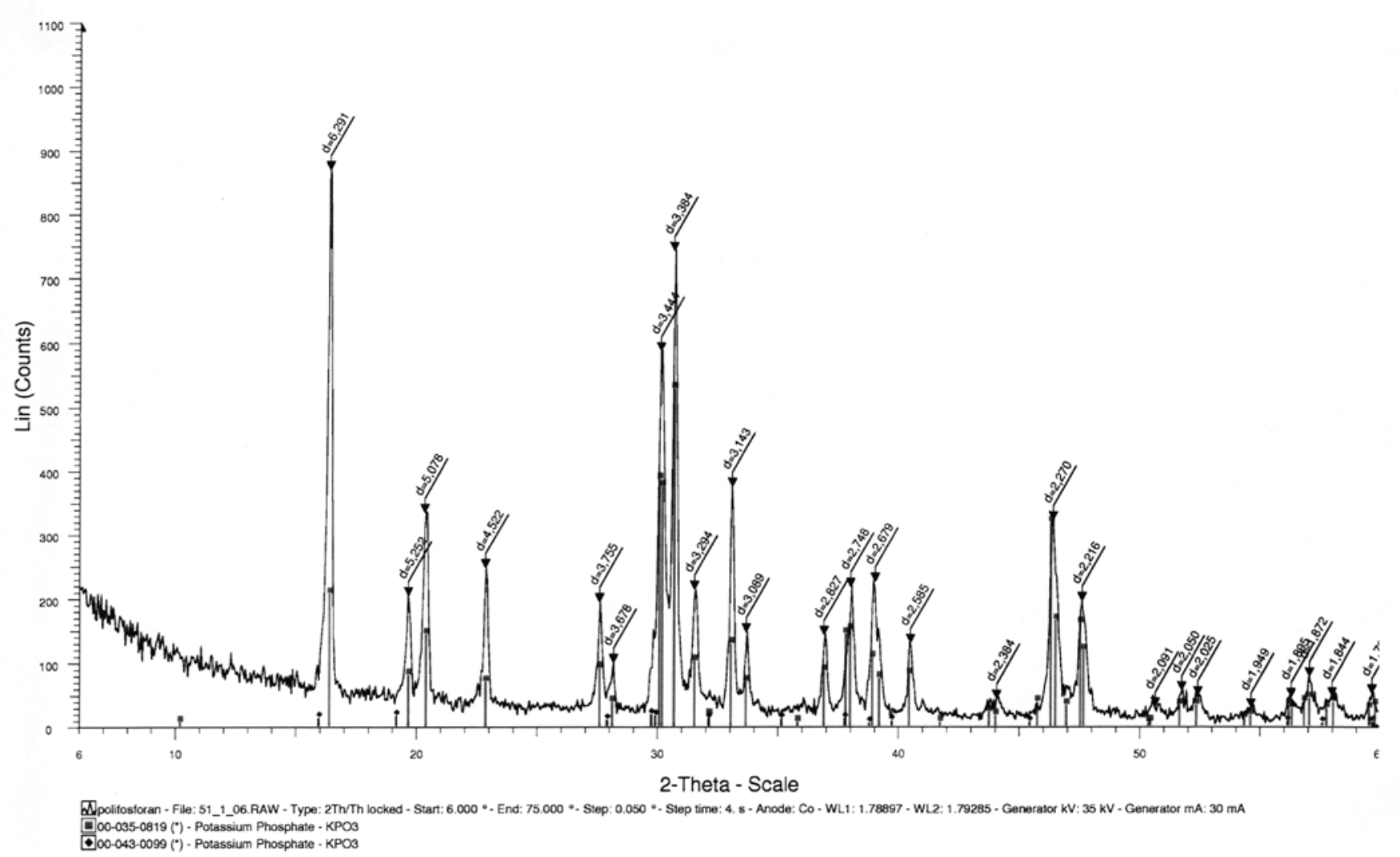

Figure 2. An X- ray diffractometer of the water insoluble phase

triphosphates: Sample (I) with $\mathrm{K}_{4} \mathrm{P}_{2} \mathrm{O}_{7}$ as main ingredient $(98.5 \%)$ and sample (II) consisting of ca. $66 \% \mathrm{~K}_{5} \mathrm{P}_{3} \mathrm{O}_{10}$ and ca. $33 \% \mathrm{~K}_{4} \mathrm{P}_{2} \mathrm{O}_{7}$. The selected samples were tested for purity in accordance with the criteria established for food products (the content of fluorine, arsenic, mercury, cadmium, lead was analyzed). The samples met the requirements for food additives and were used in the preparation of functional blends containing food grade sodium salts $\mathrm{Na}_{5} \mathrm{P}_{3} \mathrm{O}_{10}$ and $\mathrm{Na}_{2} \mathrm{H}_{2} \mathrm{P}_{2} \mathrm{O}_{7}$.

Six blends of various compositions were prepared. These were used in the preparation of selected meat products. $\mathrm{The} \mathrm{Na} / \mathrm{K}$ weight ratio in the blends prepared varied from 0.02 to 5.73 , and the ratio of triphosphates content to the total $\mathrm{P}_{2} \mathrm{O}_{5}$ content varied from 62 to $85.6 \%$. pH of a $1 \%$ water suspension and solubility in water at $20^{\circ} \mathrm{C}$ were determined for the blends and calcination products.

The recipes of the model product were developed for the phosphate blends obtained. The amount of blend added to the meat product was defined at a fixed level for all blends: $1.5 \mathrm{~g} \mathrm{P}_{2} \mathrm{O}_{5}$ per $\mathrm{kg}$ of meat product. The model product was prepared in the form of finely comminuted mortadella type meat product. A reference product containing no phosphates was prepared along with model products with the six blends added and with a commercial phosphate additive containing no potassium. Tests were performed on the prepared meat batter prior to heat processing and on the final product. Final products were tested for the yield, thermal loss, basic composition: the content of water, proteins, fat, sodium chloride, total and added phosphorus, collagen and $\mathrm{pH}$ value in accordance with the PN-ISO standards applicable to meat and meat products. In addition, an assessment of the sensory desirability and sensory profiling of the products with the use of ANALSENS 2005 software were carried out by a panel of trained judges.

\section{RESULTS}

Calcination at $300-500^{\circ} \mathrm{C}$ of the products of neutralization up to TM within the range of $1.2-1.5$ provided 20 $-51.7 \%$ of water insoluble products with orthophosphate to multiphosphate conversion rate of 78 to $98 \%$. The conversion rate $\mathrm{K}$ increased with reaction time and temperature. The separated water insoluble phase was identified by X-ray diffractometry as insoluble potassium polyphosphate (metaphosphate) $\mathrm{KPO}_{3}$ of monoclinic structure with traces of rhombic form (Fig. 2).

Depending on the desired main product of condensation, optimal reaction temperatures are as follows: $450-$ $470^{\circ} \mathrm{C}$ for the product consisting mainly of pentapotassium triphosphate, and $400-420^{\circ} \mathrm{C}$ if the desired product is tetrapotassium diphosphate. Under these conditions neutralization products of $\mathrm{TM}=2.0$ form tetrapotassium diphosphate at a yield of nearly one hundred percent ( $\mathrm{K}$ $=99.3-99.6 \%)$. The optimal duration time of calcination under the above conditions was 40 minutes. The content of the residue insoluble in the water in the $\mathrm{TM}=$ 2.0 product was below the determination limit. Calcined neutralization products of TM $1.55-1.8$ comprised mainly of pentapotassium triphosphate, the content of which, expressed as concentration of total phosphates calculated as $\mathrm{P}_{2} \mathrm{O}_{5}$ equivalent, ranged from 61 to $97.6 \%$. The content of residue insoluble in the water decreased with the increase of TM of the neutralization product. Two potassium multiphosphate products were selected for the preparation of functional blends: (1) virtually pure tetrapotassium diphosphate and (2) product containing 
Table 1. Physicochemical properties of potassium phosphates and phosphate mixtures

\begin{tabular}{|c|c|c|c|c|c|c|c|c|}
\hline \multirow[b]{2}{*}{ MATERIAL } & \multicolumn{2}{|c|}{$\begin{array}{l}\text { POTASSIUM } \\
\text { PHOSPHATES }\end{array}$} & \multicolumn{6}{|c|}{ FOOD MIXTURES } \\
\hline & 1 & 2 & $\mathrm{I}$ & II & III & IV & $\mathrm{V}$ & $\mathrm{VI}$ \\
\hline $\begin{array}{l}\text { WATER INSOLUBLE PARTS, } \\
\% \mathrm{~m} / \mathrm{m}\end{array}$ & 0 & 0,039 & 0,03 & 0,04 & 0,02 & 0,02 & 0,04 & 0,06 \\
\hline $\mathrm{pH} 1 \%$ SOLUTION & 10,2 & 10,03 & 8,50 & 8,52 & 8,55 & 8,86 & 9,20 & 8,98 \\
\hline TOTAL PHOSPHATES, $\% \quad \mathrm{P}_{2} \mathrm{O}_{5}$ & 43,2 & 46,1 & 55,00 & 54,70 & 52,40 & 53,87 & 46,95 & 50,22 \\
\hline ORTHOPHOSPHATES, \% $\mathrm{P}_{2} \mathrm{O}_{5}$ & 0,21 & 0,43 & 1,24 & 1,24 & 1,12 & 1,28 & 0,38 & \\
\hline DIPHOSPHATES, $\% \mathrm{P}_{2} \mathrm{O}_{5}$ & 42,3 & 9,63 & 10,63 & 14,96 & 19,28 & 13,96 & 12,30 & 9,41 \\
\hline TRIPHOSPHATES, $\% \mathrm{P}_{2} \mathrm{O}_{5}$ & 0,7 & 36,33 & 45,60 & 39,90 & 34,20 & 39,90 & 33,85 & 40,26 \\
\hline MASS FRACTION $\mathrm{Na} / \mathrm{K}$ & - & - & 5,73 & 2,53 & 1,47 & 1,94 & 0,02 & 0,36 \\
\hline $\begin{array}{l}\text { WATER SOLUBILITY, 20C, as \% } \\
\mathrm{P}_{2} \mathrm{O}_{5}\end{array}$ & 26,3 & 29,60 & 18,11 & 21,84 & 20,17 & 17,5 & 29,16 & 28,09 \\
\hline As, $\mathrm{mg} / \mathrm{kg}$ & $<0,25<$ & $<0,25<$ & n.a. & n.a. & n.a. & n.a. & n.a. & n.a. \\
\hline $\mathrm{F}^{-}, \mathrm{mg} / \mathrm{kg}$ & 1,2 & 1,3 & n.a. & n.a. & n.a. & n.a. & n.a. & n.a. \\
\hline $\mathrm{Cd}, \mathrm{mg} / \mathrm{kg}$ & $<0,25$ & $<0,25$ & n.a. & n.a. & n.a. & n.a. & n.a. & n.a. \\
\hline $\mathrm{Pb}, \mathrm{mg} / \mathrm{kg}$ & $<0,25<$ & $<0,25<$ & n.a. & n.a. & n.a. & n.a. & n.a. & n.a. \\
\hline $\mathrm{Hg}, \mathrm{mg} / \mathrm{kg}$ & $<0,001$ & $<0,001$ & n.a. & n.a. & n.a. & n.a. & n.a. & n.a. \\
\hline
\end{tabular}

n.a. - no analysed

significant amount of pentapotassium triphosphate and low amount of water insolubles. The tested blends (Table I) and a commercial blend, with total phosphate content of $58.0 \%$ and $\mathrm{pH}$ of a $1 \%$ suspension equal to 9.71 , were used in the application tests as additives to the model, finely comminuted, meat products.

The use of phosphate blends in the mortadella type meat products caused an increase of the $\mathrm{pH}$ of the batter: from 5.96 in the reference, phosphate-free sample, to 6.03 -6.15 in phosphate-containing samples. The increase in the $\mathrm{pH}$ was in proportion to the $\mathrm{pH}$ of the phosphate blend added. The higher the $\mathrm{pH}$ of the phosphate blend was, the higher the $\mathrm{pH}$ of the meat batter got. Contrary to the intermediate meat batter, no significant increase in the $\mathrm{pH}$ was observed in the final products, which were subjected to heat processing. The $\mathrm{pH}$ of the final products varied in the range of 6.2 to 6.3 .

The yields of the model products containing the tested blends, of the product containing the commercial blend and of the reference product were similar and varied within 96 to $98 \%$. The highest thermal loss value was observed in the reference product (phosphate-free), whereas the lowest value was attained in the product containing blend $\mathrm{V}$, rich in potassium, with thermal loss being reduced threefold.

The basic chemical composition of the model products (content of water, proteins, fat, $\mathrm{NaCl}$, total and added phosphorus, collagen and $\mathrm{pH}$ ) was, as assumed, comparable. Water content varied from 62.8 to $64.2 \%$, protein content 10.1 to $10.6 \%$, fat content 22.5 to $24.2 \%$, total phosphorus content from $2.0 \%$ in the product with no phosphate added to $3.3-3.5 \%$ in the products with phosphates added, added phosphorus content from 0.9 to $1.1 \%$ in the products with phosphates added, collagen content 1.42 to $1.60 \%$, and sodium chloride content 1.8 to $1.9 \%$. The observed degree of variability can presumably be justified by biological heterogeneity of the raw materials used. Evaluation of sensory properties - colour, odour, taste, firmness and overall desirability of the mortadella product - carried out by a panel of experts, showed little differences between products. All of the sensory properties evaluated were at a level acceptable to consumers, and the differences were too small to enable classification of the phosphate blends based on these properties.

\section{CONCLUSIONS}

Partial results of tests on potassium di- and triphosphate preparation and use in additives for meat processing have been presented. The research conducted on functional additives containing the tested phosphates has shown that both tetrapotassium diphosphate and pentapotassium triphosphate can form basis for the development of manufacturing processes and for the determination of optimal composition of potassium-enriched functional additives capable of imparting desired properties to the meat products.

Further research is to include testing of higher phosphate concentrations (in the range of 1.5 to $5.0 \mathrm{~g} / \mathrm{kg}$ ) and higher potassium content in test blends. The aim of this research is to determine the differences between potassium di- and triphosphate functions and between corresponding sodium salts in order to optimize the composition of functional additives used in the various meat products.

\section{ACKNOWLEDGEMENTS}

This research was performed as part of research project no. 1 T09B 07430 financed by the Ministry of Science and Higher Education.

\section{LITERATURE CITED}

(1) Ordinance of the Minister of Health of 23 April 2004 on approved additives and processing aids (Dz. U. No. 94, item 933).

(2) Rutkowski A., Gwiazda S.: Fosforany i ich funkcje technologiczne, Gospodarka Mięsna, 1993, 45, 23 - 27.

(3) Duda Z.: Krajowe i międzynarodowe uwarunkowania stosowania dodatków funkcjonalnych i konserwantów w przetwórstwie mięsa, Żywność. Nauka. Technologia. Jakość, 2000, 4, 5 - 26.

(4) Klettner P. G.: Wirkung unterschiedlicher Phosphate in Bruhwurst. Fleischwirtschaft, 2000, 4, 143 - 145.

(5) Rutkowski A.: Stosowanie dozwolonych substancji dodatkowych w przetwórstwie mięsa, drobiu i ryb, Hortimex Konin, 2004.

(6) Uchman W.: Substancje dodatkowe w przetwórstwie mięsa, AR Poznań, 2001.

(7) Sikorski E. (Edit.), Chemia żywności, WNT Warszawa, 2002. 
(8) Möller S., Rahn M., Schneider F.: Wirkung verschiedener Phosphatpraparate auf Konsistenz und Sensorik von Bruhwursten. Fleischwirtschaft, 2001, 8, 101103.

(9) Müller W. D., Eber M., Przytulla J.: Einfluss verschiedener Phosphat-Dosierungen auf technologische Parmeter and sensorisce Eigenschaften von Kochschinken. Fleischwirtschaft, 2000, 1, 99 - 102.

(10) Arneth W., Herold B., Hammer G. F.: Abbau von Diund Triphosphat in Bruhwurstbrat. Fleischwirtschaft. 2002, $1,78-80$.

(11) Grzmil B.: Niskoodpadowy proces kompleksowego wytwarzania produktów nawozowych o regulowanej rozpuszczalności, Pr. Nauk. Polit. Szczecińska. 542, Szczecin 1998.

(12) Cichy B., Folek S., Makała H.: Fosforany spożywcze - metody produkcji i kierunki zastosowania, Chemik, 2005, $58,424-428$.

(13) Ullmann's Encyclopaedia of Industrial Chemistry, Fifth Edition, Wiley, New York 2001. 